Review

\title{
Status and Trends of Urban Beekeeping Regulations: A Global Review
}

\author{
Tomonori Matsuzawa and Ryo Kohsaka *
}

check for

updates

Citation: Matsuzawa, T.; Kohsaka, R. Status and Trends of Urban Beekeeping Regulations: A Global Review. Earth 2021, 2, 933-942. https://doi.org/10.3390/earth2040054

Academic Editor: Charles Jones

Received: 30 September 2021 Accepted: 3 November 2021 Published: 8 November 2021

Publisher's Note: MDPI stays neutral with regard to jurisdictional claims in published maps and institutional affiliations.

Copyright: (c) 2021 by the authors. Licensee MDPI, Basel, Switzerland. This article is an open access article distributed under the terms and conditions of the Creative Commons Attribution (CC BY) license (https:/ / creativecommons.org/licenses/by/ $4.0 /)$.
Graduate School of Environmental Studies, Nagoya University, Nagoya 464-8601, Japan; mtomonor@ideacon.co.jp

* Correspondence: kohsaka.ryo@f.mbox.nagoya-u.ac.jp

\begin{abstract}
Urban beekeeping is gaining salience worldwide. Though beekeeping brings benefits to humanity, it has certain negative aspects. We conducted surveys in eight countries where urban beekeeping is practiced to understand the status of the governance of urban beekeeping. There were a wide variety of rules, ranging from detailed ones to the absence of any. The organizations creating regulations included regional governments, basic governments, and even NGOs. Regulatory items for urban beekeeping were biased toward safety, with few regulations of the other aspects, such as biodiversity conservation and apicultural production. We found a wide range of numerical provisions for this regulation type, with no scientific basis provided, and there is further need for improvements.
\end{abstract}

Keywords: urban beekeeping; pollinators; beekeeping regulations; biological conservation; biodiversity

\section{Introduction}

Pollinators are essential for human survival because they help facilitate food production [1]. Honey bees are a prime example of a species with symbolic meaning and substantial functions. However, we are facing a crisis due to the direct and indirect impacts of neonicotinoids on honey bees [2]. It is critical to improve governance to appropriately respond to this crisis and form a sustainable society [3].

Urban beekeeping has been rapidly expanding globally in major urban areas such as in Japan and South Korea in recent years [4-6]. From 2011 to 2015, the number of beekeepers in London nearly doubled [7], and it multiplied twice in Paris from 2013 to 2015 [8]. From 2016 to 2018, the numbers of hobby beekeepers in Sydney increased by $20 \%$ [9]. Despite the limited published data on urban beekeeping, a general increasing trend has been observed globally. The International Council for Local Environmental Initiatives (ICLEI) emphasizes that cities and towns can be major refuges for many insect pollinators, providing foraging and nesting sites, larval food plants, and nectar that may be less available on intensively managed farmland [10]. Urban beekeeping positively impacts agricultural functions, such as pollination, honey production, community building, environmental education, and ecosystem sustainability [11,12]. However, there is mounting evidence of the negative impacts of urban beekeeping on ecosystem services $[8,13,14]$. Governance is critical for minimizing the negative aspects and maximizing the positive aspects of urban beekeeping $[15,16]$.

To date, urban beekeeping is practiced globally on all continents except for Antarctica. However, there are limited integrated and organized sources of information regarding beekeeping regulations and governance despite practical and academic demands. The purpose of this study was to obtain a global overview of official (and partially informal or voluntary) regulations related to urban beekeeping. Such a comprehensive review serves practical, administrative, and academic purposes.

We reviewed urban beekeeping regulations, which face critical governance challenges, and summarized points to achieve sustainable urban beekeeping. This report provides an 
overview of the state of governance of urban beekeeping in eight countries. Based on the review, we identified weaknesses in governance and future research needs.

\section{Materials and Methods}

We conducted a systematic review in this study. Interviews with officials in Osaka Prefecture, Japan, were conducted via telephone and email to complement the review of documents. First, Table 1 was prepared for selecting the countries for survey. We conducted search with the key word "urban beekeeping" with the additional condition of the country name (the command being "urban beekeeping" AND "[country name]") to search for the presence of urban beekeeping in each country. Based on this configuration, the search generated 101 cases in 43 countries, as reflected in Table 1. To obtain a balanced overview, we selected seven countries from regions with significant literature results (Europe, Asia, Africa, Oceania, and the Americas).

Table 1. Number of countries and cases where urban beekeeping has been confirmed to exist. "*” Indicates seven extracted countries. In addition to Japan, eight countries were selected for the survey.

\begin{tabular}{|c|c|c|c|c|c|c|c|c|}
\hline Region & Countries & Sites & Region & Countries & Sites & Region & Countries & Sites \\
\hline \multirow[t]{6}{*}{ Americas } & Canada* & 8 & \multirow[t]{17}{*}{ Europe } & $\mathrm{UK}^{*}$ & 15 & \multirow{8}{*}{ Oceania } & Luxembourg & 1 \\
\hline & USA * & 8 & & Germany & 8 & & Norway & 1 \\
\hline & Brazil & 2 & & Netherlands & 4 & & Serbia & 1 \\
\hline & $\begin{array}{l}\text { Dominican } \\
\text { Republic }\end{array}$ & 1 & & Italy & 3 & & Slovakia & 1 \\
\hline & Mexico & 1 & & Austria & 2 & & Spain & 1 \\
\hline & Uruguay & 1 & & Belgium & 2 & & Sweden & 1 \\
\hline \multirow[t]{11}{*}{ Asia } & South Korea & 3 & & France & 2 & & Australia * & 7 \\
\hline & Singapore * & 2 & & Poland & 2 & & New Zealand * & 3 \\
\hline & Cambodia & 1 & & Slovenia & 2 & Africa & South Africa * & 1 \\
\hline & $\begin{array}{l}\text { Hong Kong/ } \\
\text { China }\end{array}$ & 1 & & Croatia & 1 & Total & 43 countries & 101 \\
\hline & India & 2 & & Czech Republic & 1 & & & \\
\hline & Indonesia & 1 & & Denmark & 1 & & & \\
\hline & Israel & 1 & & Estonia & 1 & & & \\
\hline & Malaysia & 1 & & Finland & 1 & & & \\
\hline & Philippines & 1 & & Georgia & 1 & & & \\
\hline & Taiwan/China & 1 & & Ireland & 1 & & & \\
\hline & Thailand & 1 & & Latvia & 1 & & & \\
\hline
\end{tabular}

Next, literature was collected by searching for the keywords "urban beekeeping" and "regulation" using the "AND" command, and both terms were required to be included in the title, abstract, keywords, or main text. Google was used as the search engine, and we searched for literature published from 10 November 2020 to 20 November 2020.

Based on the results, places and organizations in which urban beekeeping is practiced were identified. Given that little Japanese research is available in English to the best of our knowledge, Japan was added to the list as the eighth country. Thus, the eight studied countries were the United Kingdom, South Africa, the United States, Canada, Australia, New Zealand, Singapore, and Japan.

For the eight countries, the national, state, municipality, and local regulations, as well as rules pertaining to urban beekeeping, were collected. Relevant information and references were primarily collected from government websites, and additional information was collected from relevant organizations, such as beekeeping associations. For certain countries, there were existing databases (i.e., those from the municipality and state levels in the United States and at the state level in Australia), and information from other countries was collected through individual state websites and relevant organizations with certain 
limitations in accuracy and comprehensiveness. In the United States, Canada, and Australia, the number of municipalities with rules on urban beekeeping was extensive; thus, we limited our scope to 37 municipalities for the United States, 14 municipalities for Canada, and 38 municipalities for Australia. We selected approximately 10 cities with the highest frequency in the search results and conducted a more detailed survey using the methods described below.

Given the exploratory nature of this study, we did not distinguish between official laws (hard laws) and voluntary or customary ones (soft laws). We classified the regulatory items related to urban beekeeping based on their contents and according to the frameworks of Larson et al. [15], Sponsler and Bratman [16], and Salkin [17]. Larson et al. [15] identified 13 types of regulatory ordinances in residential areas in the United States: stormwater/flood mitigation, biological conservation, water quality protection, pest control, aesthetic maintenance, safety, encroachment avoidance, land conservation, water conservation, disease avoidance, property values, heat mitigation, and less allergen avoidance ordinances. We adopted the biological conservation, pest control, and safety factors from Larson et al. [15] because they are considered most relevant to urban beekeeping (Table 2).

Table 2. Relationship between our framework and previous studies for regulatory items.

\begin{tabular}{|c|c|c|}
\hline Our Framework & Larson et al. Framework [15] & $\begin{array}{l}\text { Sponsler and Bratman } \\
\text { Framework [16] }\end{array}$ \\
\hline Pollination services & - & Pollination services \\
\hline Biological conservation & Biological conservation & Resource competition \\
\hline Pest control & Pest control & $\begin{array}{l}\text { Disease transmission to other } \\
\text { insects }\end{array}$ \\
\hline Safety & Safety & Stinging \\
\hline Apicultural products & - & $\begin{array}{l}\text { Apicultural products and } \\
\text { livelihoods }\end{array}$ \\
\hline Community formation & - & Expert community formation \\
\hline- & Stormwater/flood mitigation & - \\
\hline- & Water quality protection & - \\
\hline- & Aesthetic maintenance & - \\
\hline- & Encroachment avoidance & - \\
\hline- & Land conservation & - \\
\hline- & Water conservation & - \\
\hline- & Disease avoidance & - \\
\hline- & Property values & - \\
\hline- & Heat mitigation & - \\
\hline- & Less allergen avoidance & - \\
\hline
\end{tabular}

Sponsler and Bratman [16] classified the socio-ecological aspects of urban beekeeping into six categories: pollination services, resource competition, disease transmission to other insects, stinging, apicultural products and livelihoods, and expert community formation. Based on these frameworks, we applied the following six criteria to each regulatory objective and (Table 2):

- Pollination services: Items in this category influence the extent of the pollination function of plants in urban areas. The service can be performed by either wild or managed bees.

- Biological conservation: Items in this category influence the magnitude of competition for nectar resources with other honey bees (e.g., Apis mellifera). 
- Pest Control: Items in this category influence the extent of infectious diseases and parasites between honey bees or other pollinators.

- Safety: Items in this category concern the negative/nuisance behaviors of honey bees to humans or pets, including stings, droppings, and noise. This category also includes the probability of physical contact between honey bees and humans and potential hazards, such as honey bee stinging incidents.

- Apicultural products: Items in this category concern the control of the production of honey, beeswax, and other products. This category also includes the quantitative relationship between nectar resources and hives.

- Community formation: Items in this category influence the social aspects of and community formation through urban beekeeping.

Salkin [17] categorized the regulatory items for urban beekeeping into eight types: classification of bees, lot size and colony density, setbacks, flyway barriers, access to water, permits and registration requirements, apiary identification signs, and fire safety regulations). We considered the "apiary identification signs" of Salkin to be the same as registration and incorporated them into the registration section (Table 3). We also added four items (area restrictions/zoning, neighborhood awareness, queen bee management, and training requirements) that we frequently identified during the systemic review (Table 3).

Table 3. Relationship between our framework and previous study for regulatory objectives.

\begin{tabular}{cc}
\hline Our Framework & Salkin Framework [17] \\
\hline Registration & $\begin{array}{c}\text { Permits and registration requirements; } \\
\text { apiary identification signs }\end{array}$ \\
\hline Number of hives/densities & Lot size and colony density \\
\hline Area restrictions/zoning & Flyway barriers \\
\hline Installation of barriers & Setbacks \\
\hline Setbacks & Classification of bees \\
\hline Permitted species or subspecies & Access to water \\
\hline Water supply & - \\
\hline Neighborhood awareness & - \\
\hline Queen bee management & Fire safety regulations \\
\hline Training requirements &
\end{tabular}

In summary, we utilized the regulatory objectives and items in the Larson et al. [15], Salkin [17], and Sponsler and Bratman [16] frameworks, as well as information from the systematic review, to create the regulatory frameworks for this study.

\section{Results}

The results are presented by country (Table 4). We did not find any cases in which national governments set the rules or regulations for urban beekeeping. For Canada, Australia, and New Zealand, we identified rules at the provincial or regional and municipal levels that formulated the rules for urban beekeeping. In contrast, municipalities formulated the rules and regulations in the United States and South Africa. 
Table 4. Existence of urban beekeeping rules and distribution of Apis mellifera and competing related native species.

"-" means N/A and " $\bigcirc$ " represents the existence of a rule document developed by the relevant organization.

\begin{tabular}{|c|c|c|c|c|c|c|}
\hline \multirow[b]{2}{*}{ Country } & \multicolumn{4}{|c|}{ Rules Established by } & \multicolumn{2}{|c|}{ Distribution } \\
\hline & $\begin{array}{c}\text { National } \\
\text { Government }\end{array}$ & $\begin{array}{c}\text { State/Prefecture/ } \\
\text { Regional Governments }\end{array}$ & $\begin{array}{c}\text { Cities/Basic } \\
\text { Municipalities }\end{array}$ & NGOs & $\begin{array}{l}\text { Naturally } \\
\text { Distributed } \\
\text { Species }\end{array}$ & $\begin{array}{c}\text { Competitive } \\
\text { Related } \\
\text { Species }\end{array}$ \\
\hline $\begin{array}{l}\text { United } \\
\text { Kingdom }\end{array}$ & - & - & - & 0 & A.m. mellifera & - \\
\hline South Africa & - & - & 0 & 0 & $\begin{array}{l}\text { A.m. capensis } \\
\text { A.m. scutellata }\end{array}$ & - \\
\hline United States & - & - & 0 & 0 & - & - \\
\hline Canada & - & 0 & 0 & 0 & - & - \\
\hline Australia & - & O & 0 & 0 & - & - \\
\hline New Zealand & - & 0 & 0 & 0 & - & - \\
\hline Singapore & - & - & - & - & - & $\begin{array}{c}\text { A. cerana } \\
\text { A. florea } \\
\text { A. dorsata } \\
\text { A. andreniformis } \\
\text { A. koschevnikovi }\end{array}$ \\
\hline Japan & - & - & - & - & - & A. cerana \\
\hline
\end{tabular}

In the United States, Canada, Australia, New Zealand, and South Africa, rules have been established by official bodies (e.g., states and municipalities) regarding urban beekeeping. In contrast, official regulations were not identified in the United Kingdom, Singapore, and Japan. In Singapore, though bees are regarded as nuisances, beekeeping is permitted in urban areas if it is declared to be a hobby and not for commercial purposes.

In Japan, there are no regulations or rules specific to urban beekeeping at the prefectural and municipal levels, and honey bees can be kept freely (there are rules and regulations for beekeeping as a husbandry activity). The Osaka Prefecture is an exception. This city has a setback regulation that practically prohibits beekeeping in urban areas; however, this regulation is not intended to be applied to urban areas (as explained in interviews by a city official).

The majority of the identified rules and regulations have been published in the form of acts, ordinances, and guidelines. These included both mandatory and voluntary rules. We did not distinguish between the two because our objective was to obtain an overview of the global regulation trends. In certain cases, non-governmental organizations (NGOs) had developed or published urban beekeeping guidelines. In the United Kingdom in particular, NGOs have initiated the management of urban beekeeping activities.

Apis mellifera are naturally distributed in the United Kingdom and South Africa, but they are considered alien species in the other six countries. Meanwhile, in Singapore and Japan, the indigenous species is Apis cerena (also known as Oriental honey bees), and they are naturally distributed. Though they are potential competitors to Apis mellifera, Apis cerena are used in traditional beekeeping throughout their natural range in Asia, for instance in Japan [6], Thailand [18], and Indonesia [19].

The most frequent regulation items were found to be registrations, particularly those related to the number/density of hives, area restrictions/zoning, the installation of barriers, setbacks, permitted species or subspecies, water supply, neighborhood awareness, queen bee management, training requirements, and fire safety regulations.

An overview of the relationships among the regulatory objectives and regulatory items is illustrated below (Figure 1). Based on the results, the most common regulatory item category was found to be safety. 


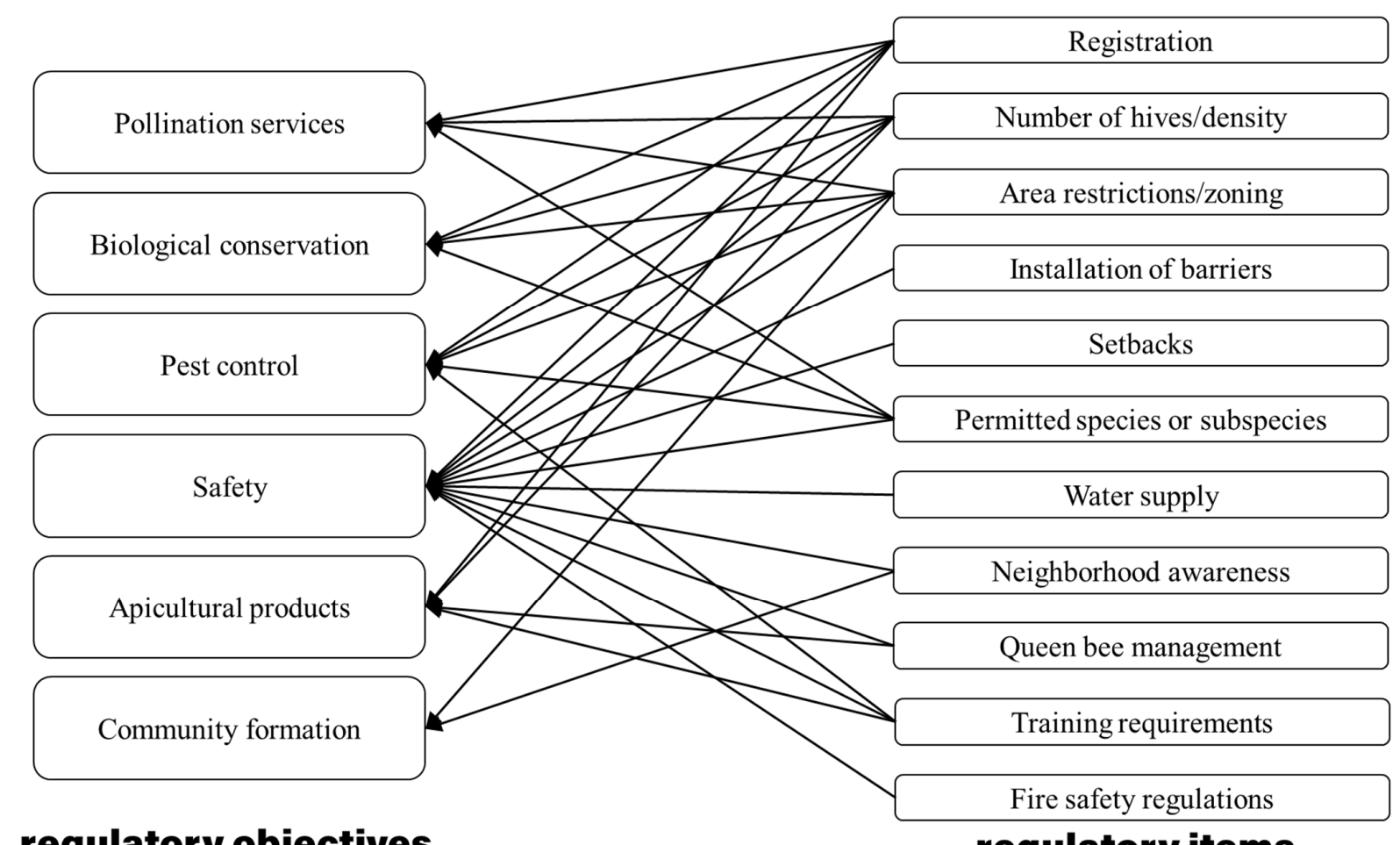

regulatory objectives

regulatory items

Figure 1. Relationships among regulatory objectives and items for urban beekeeping.

The items also exhibited diversity. For example, a wide range of numerical limits were found to have been set for hive density, setbacks, and barriers (Table 5).

Table 5. Regulatory items for urban beekeeping.

\begin{tabular}{|c|c|c|}
\hline Regulatory Item & Rule & Diversity/Range \\
\hline Number/density of hives & $\begin{array}{c}\text { Number of hives that can be placed in an } \\
\text { apiary }\end{array}$ & $\begin{array}{c}\text { Limit by number/density per area/minimum } \\
\text { area; } \\
\text { one to unlimited }\end{array}$ \\
\hline Area restrictions/zoning & $\begin{array}{l}\text { Restrictions on the area where nest boxes can } \\
\text { be placed }\end{array}$ & $\begin{array}{c}\text { Restricted to some residential and commercial } \\
\text { areas; } \\
\text { possible in entire area }\end{array}$ \\
\hline Installation of barriers & $\begin{array}{l}\text { Requiring a fence surrounding the hive with } \\
\text { hedges, lattices, and boards to guide the bees } \\
\text { upward }\end{array}$ & $\begin{array}{l}\text { Materials (boards and hedges); } \\
\text { height of fence }(3-10 \mathrm{ft}) \\
6 \mathrm{ft} \text { is most common rule }\end{array}$ \\
\hline Setbacks & $\begin{array}{l}\text { Keep hives away from property boundaries } \\
\text { and adjacent residences, roads, and public } \\
\text { facilities }\end{array}$ & $\begin{array}{l}\text { Distance from property boundary/public } \\
\text { space/dwellings/road/etc.; } \\
\quad 1-1000 \mathrm{ft} ; \\
25 \mathrm{ft} \text { is most common rule }\end{array}$ \\
\hline Water supply & Installation of a watering hole in the apiary & $\begin{array}{l}1-30 \mathrm{ft} \text {; } \\
\text { not limiting distance is also common }\end{array}$ \\
\hline
\end{tabular}

The hive density limit is typically defined as the maximum number of hives that can be installed in an apiary (e.g., up to four hives per location in Wellington, New Zealand [20]) or per a certain site area size (e.g., two hives maximum for less than $10,000 \mathrm{ft}^{2}$ and up to four hives for over 10,000 $\mathrm{ft}^{2}$ in Vancouver, Canada [21]). It was not always specified. In contrast, the minimum area required for the installation of hive boxes was sometimes stipulated, e.g., in Dakota City, NE, USA [22]. 
The setback specifies the minimum distance from the property boundary or adjacent dwelling to the hive boxes. The variation in this rule was found to be the highest, even within the same country, with the smallest setback distance being $1 \mathrm{ft}$ (City of Dayton, WA, USA [23]) and the largest being $1000 \mathrm{ft}$ (City of Campbell, CA, USA [24]). We also found that it is common to specify separate distances to different site boundaries, including those to public spaces, such as roads and schools, and adjacent dwellings. In addition, many cases were found to combine setback and barrier regulations (e.g., relaxing the setback distance when a barrier is present [25]).

Many regulations and rules were found to require the installation of barriers; most rules require $6 \mathrm{ft}$ barriers, and there is a range of 3-10 ft [25-27]. The review showed that it is common to stipulate the water supply of apiaries, and in some cases, their distance from the hive [28]. We even discovered cases of prohibiting/allowing specific areas according to the zoning classifications of the city plan [29].

\section{Discussion}

\subsection{Bias in Regulatory Items}

The regulatory items extracted in this study typically agreed with those in previous reviews $[16,30]$. We found that the rules and regulations for urban beekeeping tend to focus more on issues related to the safety of urban dwellers than on ecological or productionrelated aspects.

While positive impacts of beekeeping, such as food production, pollination functions, community building, and environmental education, have been widely recognized in recent years, various negative aspects of urban beekeeping have also been recognized $[8,13,14,31,32]$. The data we collected revealed that current urban beekeeping rules may be biased towards resident safety and do not adequately address the negative aspects of urban beekeeping. For the balanced expansion of urban beekeeping, safety, biodiversity, apicultural production, and quarantine aspects should all be considered. In the following sections, we illustrate certain pitfalls that are not fully covered in the current regulatory systems for urban beekeeping.

\subsection{Hive Density}

London is among the cities with the most active urban beekeeping sites, with many participants. However, honey yields are declining in certain areas. This is likely due to the high density of hives [32-34]. In addition to honey bees, various insects, butterflies, and birds also use nectar and pollen. Thus, the presence of many honey bees in urban areas can potentially harm these other flower users $[8,13,14]$. Some studies have demonstrated negative impacts of beekeeping on native pollinators $[8,35,36]$. Controlling the density of hive boxes in urban areas is considered to be one of the most effective methods to resolve this issue [16]; however, little research has been done in this area thus far.

\subsection{Infectious Diseases, Pests and Biodiversity}

There are concerns related to both wild and managed honey bees. Managed honey bees can potentially transfer infections and parasites to wild bees and other species. Despite the fact that nearly all countries and regions have beekeeping quarantine requirements, there appear to be no rules to prevent the spread of parasites and diseases.

Apis mellifera is a bee species widely distributed from Africa to Europe, and it is divided into approximately 30 subspecies depending on the region [35]. An initiative has been launched to conserve the regionally endemic honey bee subspecies in Europe [36]. In the future, conserving biodiversity at the genetic level will become even more critical. In recent years, the frequency of recorded spillover cases of honey bee pathogens to other arthropods, including wild bees, has dramatically increased [37]. Particular attention should be paid to Asia, where native species of the same genus Apis exist. In the future, it may be necessary to establish rules for urban beekeeping to protect native honey bee 
species in Singapore and Japan. These considerations are not well-stipulated in current regulations.

\subsection{Scientific Evidence}

There are a wide range of regulatory items for urban beekeeping. Certain elements are instrumental in neighborhood awareness and training and effective in avoiding problems, while other elements, such as fence and setback requirements, have questionable rationales. While fencing is one of the most frequent regulations, aiming to guide the flight path of bees upward by setting up a fence around the hive may be ineffective. The most common fence height requirement is $6 \mathrm{ft}$, and the range is range from 3 to $10 \mathrm{ft}$. Six feet is similar to the height of human beings, but there is no scientific evidence for setting such a fence height for beekeeping.

Another example is setbacks. The setback distance to the property boundary can prevent honey bees from competing with neighboring humans or pets in their flight path The required distance can range from 1 to $1000 \mathrm{ft}$, and similar to the fencing rules, there is no or little scientific evidence provided for these distances.

We observed a variety of rules limiting the number of installed hives. These included cases where the number of hives is fixed, the maximum number varies depending on the size of the site area, or there is no specific regulation. Thus, there are a wide range of numerical provisions for this regulation type with no provided scientific basis. Scientists in ecology and other fields can provide constructive suggestions for policies in this area. In a future study, we will conduct a more detailed survey of the relationship between regulatory items and scientific evidence in the United States and Australia.

\subsection{Modification of Rules and Clarification of Definitions}

Urban beekeeping is a recent phenomenon, and cities such as New York and Los Angeles have amended their ordinances to allow for beekeeping in urban areas around $2010[16,38,39]$. In contrast, some cities have explicitly banned bees because they are considered nuisances (e.g., San Clemente, CA, USA). Whether beekeeping is possible or prohibited in many areas is ambiguous because it is not well-defined whether bees are considered a nuisance organism [40]. Experts have identified that regulations before the development of urban beekeeping, such as those of the City of Toronto (Canada) and Osaka Prefecture (Japan), may be outdated, with setback distances of 30 and $20 \mathrm{~m}$, respectively, that in practice prevent beekeeping in urban areas [40]. Because most urban beekeepers are satisfied with keeping only a few hives, it is critical to re-examine the current rules to meet the needs of urban dwellers. Clarifying the conditions under which urban beekeeping is possible can help reduce the nuisances related to urban beekeeping.

\section{Conclusions}

We surveyed eight countries where urban beekeeping is practiced to determine which urban beekeeping rules currently exist. We found rules developed by governments and NGOs, and no rules were identified in some areas. Regulatory items for urban beekeeping were found to be biased toward safety, with few regulations on the other aspects, such as biodiversity conservation and apicultural production. The development of scientifically based rules and policies or evidence-based policymaking is necessary for the proper promotion of urban beekeeping.

Author Contributions: Conceptualization, R.K.; methodology, T.M.; validation, T.M.; writingoriginal draft reparation, T.M.; writing-review and editing, T.M. and R.K.; visualization, T.M.; supervision, R.K.; project administration R.K.; funding acquisition, R.K. and T.M. All authors have read and agreed to the published version of the manuscript.

Funding: This work was supported by JSPS KAKENHI Grant Numbers JSPS KAKENHI Grant Numbers JP21K18456; JP20K12398; JP16KK0053; JP17K02105; JST RISTEX Grant Number JPMJRX20B3. This work was also supported by IDEA Consultants, Inc. 
Acknowledgments: The authors would like to thank Yuta Uchiyama, Jay Mar D. Quevedo, and Miyake Yoshitaka for critical and helpful comments on earlier versions of this article.

Conflicts of Interest: The authors declare no conflict of interest.

\section{References}

1. Sukhdev, P.; Wittmer, H.; Schroter-Schlaack, C.; Nesshover, C.; Bishop, J.; Brink, P.; Gundimeda, H.; Kumar, P.; Simmons, B. The Economics of Ecosystems and Biodiversity: Mainstreaming the Economics of Nature: A synthesis of the Approach, Conclusions and Recommendations of TEEB; United Nations Environment Programme: Nairobi, Kenya, 2010.

2. Giorio, C.; Safer, A.; Sánchez-Bayo, F.; Tapparo, A.; Lentola, A.; Girolami, V.; van Lexmond, M.B.; Bonmatin, J.-M. An Update of the Worldwide Integrated Assessment (WIA) on Systemic Insecticides. Part 1: New Molecules, Metabolism, Fate, and Transport. Environ. Sci. Pollut. Res. Int. 2021, 28, 11716-11748. [CrossRef] [PubMed]

3. Intergovernmental Science-Policy Platform on Biodiversity and Ecosystem Services. Summary for Policymakers of the Assessment Report of the Intergovernmental Science-Policy Platform on Biodiversity and Ecosystem Services (IPBES) on Pollinators, Pollination and Food Production; IPBES: Bonn, Germany, 2016.

4. Lorenz, S.; Stark, K. Saving the honey bees in Berlin? A case study of the urban beekeeping boom. Environ. Sociol. 2015, 1, 116-126. [CrossRef]

5. Barnett, L. Why London's Beekeepers are a Growing Band. Available online: https://www.independent.co.uk/environment/ why-londons-beekeepers-are-a-growing-band-476750.html (accessed on 13 January 2020).

6. Kohsaka, R.; Park, M.S.; Uchiyama, Y. Beekeeping and honey production in Japan and South Korea: Past and present. J. Ethn. Foods 2017, 4, 72-79. [CrossRef]

7. Rothman, L. London's Urban Beekeeping Scene is Exploding. 2015. Available online: https://www.vice.com/en_us/article/z4 gd44/londons-urban-beekeeping-scene-is-exploding (accessed on 3 January 2020).

8. Ropars, L.; Dajoz, I.; Fontaine, C.; Muratet, A.; Geslin, B. Wild Pollinator Activity Negatively Related to Honey Bee Colony Densities in Urban Context. PLoS ONE 2019, 14, e222316. [CrossRef] [PubMed]

9. Daniel, S. Why Do Some Sydney Councils Encourage Urban Beekeeping but Avoid Handling Complaints? Available online: https:/ / www.abc.net.au/news/2018-03-15/urban-beekeeping-curious-sydney-why-some-councils-dont-regulate/9492 094? nw=0\&r=Interactive (accessed on 5 November 2021).

10. Wilk, B.; Rebollo, V.; Hanania, S. A Guide for Pollinator-Friendly Cities: How can Spatial Planners and Land-Use Managers Create Favourable Urban Environments for Pollinators? Available online: https://www.iucn.org/sites/dev/files/local_authorities_ guidance_document_en_compressed.pdf (accessed on 30 October 2021).

11. Skelton, J. Adventures in Urban Beekeeping. Briarpatch 2006, 35, 14-17.

12. Matsuzawa, T.; Kohsaka, R.; Uchiyama, Y. Application of environmental DNA: Honey bee behavior and ecosystems for sustainable beekeeping. In Modern Beekeeping-Bases for Sustainable Production; IntechOpen: London, UK, 2020. [CrossRef]

13. Herbertsson, L.; Lindström, S.A.; Rundlöf, M.; Bommarco, R.; Smith, H.G. Competition between managed honey bees and wild bumblebees depends on landscape context. Basic Appl. Ecol. 2016, 17, 609-616. [CrossRef]

14. Lindström, S.A.M.; Herbertsson, L.; Rundlöf, M.; Bommarco, R.; Smith, H.G. Experimental evidence that honey bees depress wild insect densities in a flowering crop. Proc. R. Soc. B: Biol. Sci. 2016, 283, 20161641. [CrossRef] [PubMed]

15. Larson, K.L.; Andrade, R.; Nelson, K.C.; Wheeler, M.M.; Engebreston, J.M.; Hall, S.J.; Avolio, M.L.; Groffman, P.M.; Grove, M.; Heffernan, J.B.; et al. Municipal regulation of residential landscapes across US cities: Patterns and implications for landscape sustainability. J. Environ. Manag. 2020, 275, 111132. [CrossRef]

16. Sponsler, D.B.; Bratman, E.Z. Beekeeping in, of, or for the City? A Socioecological Perspective on Urban Apiculture. People Nat. 2021, 3, 550-559. [CrossRef]

17. Salkin, P.E. Honey, It's All the Buzz: Regulating Neighborhood Beehives. Boston Coll. Environ. Aff. Law Rev. $2012,39,55-71$.

18. Wongsiri, S.; Chanchao, C.; Deowanish, S.; Aemprapa, S.; Chaiyawong, T.; Petersen, S.; Leepitakrat, S. Honey bee diversity and beekeeping in Thailand. Bee World 2000, 82, 20-29. [CrossRef]

19. Gratzer, K.; Susilo, F.; Purnomo, D.; Fiedler, S.; Brodschneider, R. Challenges for beekeeping in Indonesia with autochthonous and introduced bees. Bee World 2019, 96, 40-44. [CrossRef]

20. Wellington City Council Guidelines for Community Beekeeping on Public Land. Available online: https://wellington.govt.nz/-/ media/dogs-and-other-animals/animals/files/bee-guidelines.pdf (accessed on 30 October 2021).

21. Urban Honey Beekeeping, City of Vancouver. Available online: https://bylaws.vancouver.ca/bulletin/U001.pdf (accessed on 30 October 2021).

22. Dakota City, Nebraska Code of Ordinances. Municode. Available online: https://library.municode.com/ne/dakota_city/codes/ code_of_ordinances?nodeId=COOR_CH6AN_ARTIIBE (accessed on 30 October 2021).

23. Dayton, Washington Code of Ordinances. Municode. Available online: https://library.municode.com/wa/dayton/codes/code_ of_ordinances?nodeId=COOR_TIT11ZOCO_CH11-03REZO_11-03.105BE (accessed on 30 October 2021).

24. Campbell, California Code of Ordinances. Municode. Available online: https://library.municode.com/ca/campbell/codes/ code_of_ordinances?nodeId=TIT7AN_CH7.28BE (accessed on 30 October 2021).

25. Anniston, Alabama Code of Ordinances. Municode. Available online: https://library.municode.com/al/nniston/codes/code_ of_ordinances?nodeId=CO_CH4ANCO_ARTIINGE (accessed on 30 October 2021). 
26. Anchorage, Alaska Code of Ordinances. Municode. Available online: https://library.municode.com/ak/anchorage/codes/ code_of_ordinances?nodeId=TIT21LAUSPLNECOFFJA120 (accessed on 30 October 2021).

27. Allen Park, Michigan Code of Ordinances. Municode. Available online: https://library.municode.com/mi/allen_park/codes/ code_of_ordinances?nodeId=PTIICOOR_CH6AN_ARTIINGE (accessed on 30 October 2021).

28. Concord, New Hampshire Code of Ordinances. Municode. Available online: https://library.municode.com/nh/concord/codes/ code_of_ordinances?nodeId=TITIVZOCO_CH28ZOOR_ART28-5SUST_28-5-44KEBE (accessed on 30 October 2021).

29. Citrus Heights, California Code of Ordinances. Municode. Available online: https://library.municode.com/ca/citrus_heights/ codes / code_of_ordinances?nodeId=COOR_CH106ZO_CH106.24REOPSPZODI_S106.24.030REOPSPDIALLAUSPERE (accessed on 30 October 2021).

30. Paynter, G. Review of Legislation, By-laws, Ordinances Regulations and Guidelines Regarding Urban Beekeeping. 2015. Available online: https: / / studylib.net/doc/18913050 (accessed on 30 September 2021).

31. Rahimian, R.; Shirazi, F.M.; Schmidt, J.O.; Klotz, S.A. Honeybee stings in the era of killer bees: Anaphylaxis and toxic envenomation. Am. J. Med. 2020, 133, 621-626. [CrossRef]

32. Davenport, J. Celebrity Beekeepers Told to Buzz off. Available online: https://www.standard.co.uk/news/london/celebritybeekeepers-told-to-buzz-off-7854420.html (accessed on 13 January 2020).

33. Rise in Urban Beekeeping in UK May have Gone too Far, Scientists Warn. Available online: http://www.sussex.ac.uk/broadcast/ $\mathrm{read} / 20465$ (accessed on 3 January 2020).

34. Henry, M.; Rodet, G. Controlling the Impact of the Managed Honey Bee on Wild Bees in Protected Areas. Sci. Rep. 2018, 8, 9308. [CrossRef] [PubMed]

35. Sheppard, W.S.; Meixner, M.D. Apis Mellifera Pomonella, a New Honey Bee Subspecies from Central Asia. Apidologie 2003, 34, 367-375. [CrossRef]

36. Fontana, P.; Costa, C.; di Prisco, G.; Ruzzier, E.; Annoscia, D.; Battisti, A.; Caoduro, G.; Carpana, E.; Contessi, A.; Dal Lago, A.; et al. Appeal for biodiversity protection of native honey bee subspecies of Apis mellifera in Italy (San Michele all'Adige declaration). Bull. Insectology 2018, 71, 257-271.

37. Nanetti, A.; Bortolotti, L.; Cilia, G. Pathogens spillover from honey bees to other arthropods. Pathogens 2021, 10, 1044. [CrossRef] [PubMed]

38. Smith, D. Los Angeles Passes Urban Beekeeping Law. Available online: https://search.proquest.com/docview/1722263717 ?accountid=12653 (accessed on 14 October 2015).

39. Kudler, A.G. Backyard Beekeeping is Finally Legal in Los Angeles. Available online: https://la.curbed.com/2015/10/15/99110 92/backyard-beekeeping-los-angeles (accessed on 13 January 2020).

40. Berquist, M.; Bird, A.; Dean, M.G.; Law, R.B.; Lee, S.; Panesar, H. Towards a New Approach to Beekeeping Policy in Urban Ontario At the Request of Sustain Ontario; University of Toronto: Toronto, ON, Canada, 2012; pp. 1-31. Available online: https:// sustainontario.com/custom/uploads/2012/12/FINAL-REPORT-Urban-Beekeeping-Policy-in-Ontario-December-2012.pdf (accessed on 30 September 2021). 